\title{
Biology and Management of Goosegrass (Eleusine indica (L.) Gaertn.) in Ornamental Plant Production'
}

Shawn Steed, Christopher Marble, Nathan S. Boyd, Andrew MacRae, and Kiran Fnu ${ }^{2}$

\section{Species Description}

\section{Class}

Monocotyledonous plant

\section{Family}

Poaceae (grass family)

\section{Other Common Names}

Indian goosegrass, wiregrass, crowfootgrass

\section{Life Span}

Summer annual but may survive as a short-lived perennial in tropical areas.

\section{Habitat}

Terrestrial habitat. Commonly distributed in cultivated and abandoned fields, open ground, gardens, lawns, road sides, and railroad tracks.

\section{Distribution}

It occurs in most of the tropics and the United States and ranges into northeastern Canada.

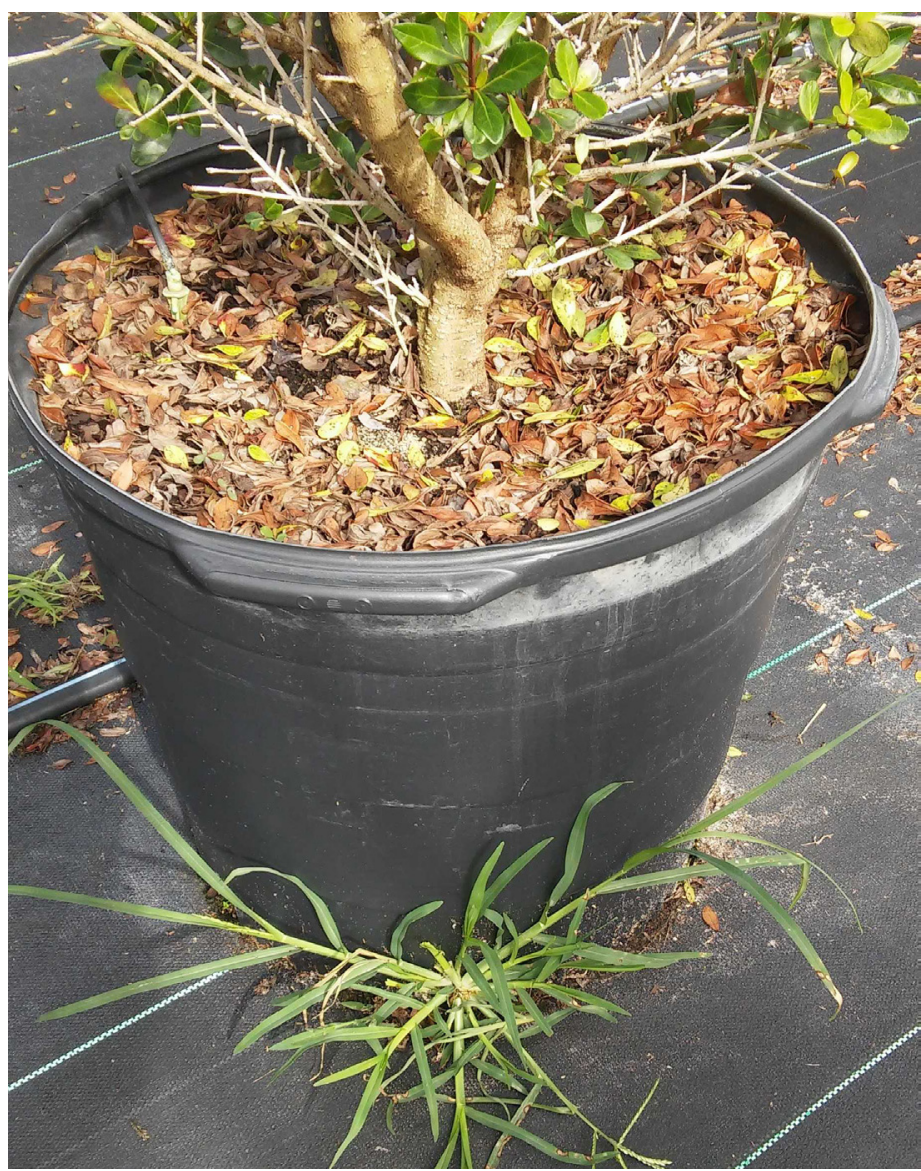

Figure 1. Goosegrass growing out of the drain hole of a nursery container.

Credits: Shawn Steed, UF/IFAS

1. This document is ENH1274, one of a series of the Environmental Horticulture Department, UF/IFAS Extension. Original publication date December 2016. Visit the EDIS website at http://edis.ifas.ufl.edu.

2. Shawn Steed, multi-county environmental horticulture production Extension agent III, UF/IFAS Extension Hillsborough County; Chris Marble, assistant professor, UF/IFAS Mid-Florida Research and Education Center; Nathan S. Boyd, associate professor, UF/IFAS Gulf Coast REC; Andrew W. MacRae, former assistant professor, UF/IFAS GCREC; and Kiran Fnu, former biological scientist, UF/IFAS GCREC; UF/IFAS Extension, Gainesville, FL 32611.

The Institute of Food and Agricultural Sciences (IFAS) is an Equal Opportunity Institution authorized to provide research, educational information and other services only to individuals and institutions that function with non-discrimination with respect to race, creed, color, religion, age, disability, sex, sexual orientation, marital status, national origin, political opinions or affiliations. For more information on obtaining other UF/IFAS Extension publications, contact your county's UF/IFAS Extension office. 


\section{Growth Habit}

Tufted grass with prostrate or upright growth. Tends to form a low growing rosette with white colored leaf sheath at the base (Figure 2). Goosegrass does not root at nodes of growing stems.
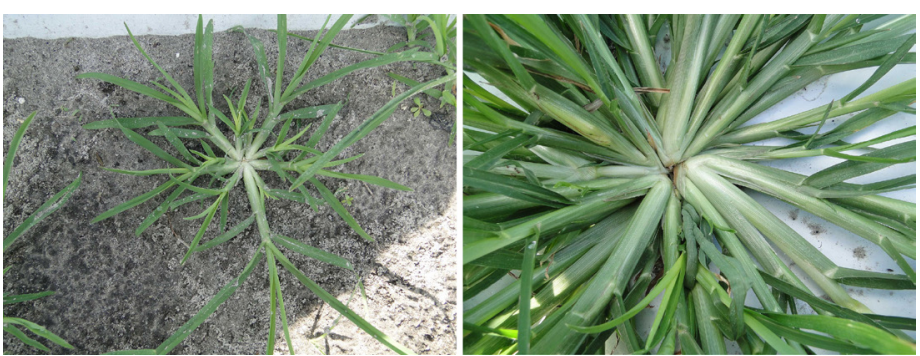

Figure 2. Goosegrass seedling (left) and mat-like rosette (right). Credits: Nathan S. Boyd, UF/IFAS

\section{Seedling}

The first leaf that emerges extends about 0.4 in $(1 \mathrm{~cm})$ in length and lies parallel to the soil. The ligule (a scale at the attachment of the leaf sheaf to the leaf blade) is membranous and fringed. The stem or the leaf sheath (part where the leaf blade wraps around the stem) is broad and tends to be white in color. The leaves are folded (flattened) and glabrous (no hairs).

\section{Shoot}

The stems are flattened and branching with few to no hairs along the edges and fleshy at the base. Stems tend to be prostrate but can grow erect. The base of the stem is whitish or pale-green in color (Figures 2 and 3 ). The leaves can be up to $1 \mathrm{ft}$. $(0.3 \mathrm{~m})$ long and generally hairless but may be slightly pubescent (hairs present) at the base. Leaves are laterally flattened or folded (Figure 3). A short jagged membranous ligule is present.

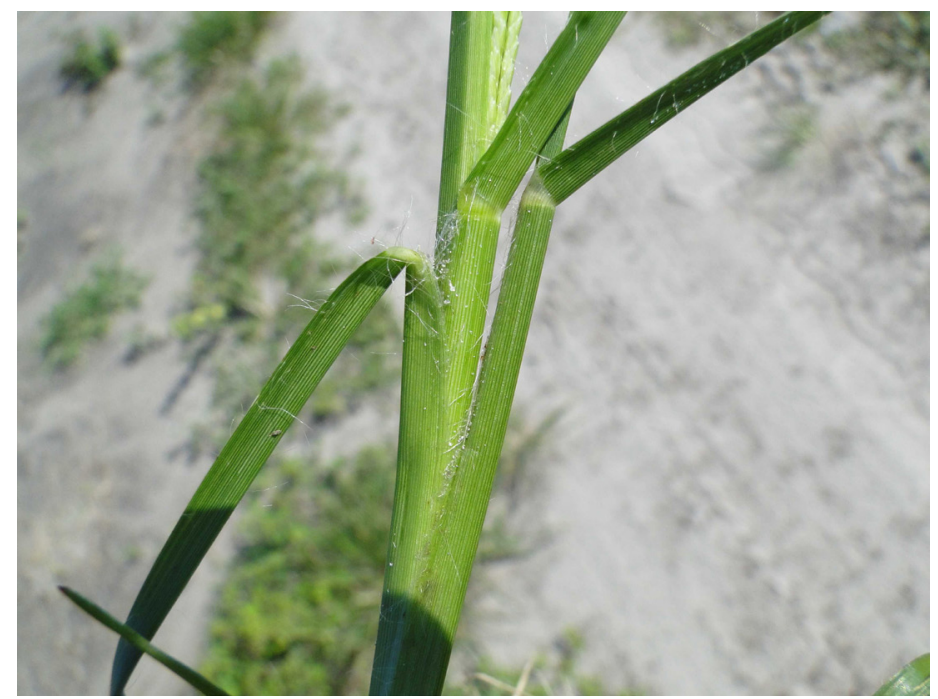

Figure 3. Goosegrass stem.

Credits: Nathan S. Boyd, UF/IFAS

\section{Roots}

Fibrous root system.

\section{Inflorescence}

The flowering portion or inflorescence is composed of 2-13 flattened, shiny, finger-like spikes that emerge from a common point. Each spike is composed of two rows of sessile spikelets (flowering parts attached at their base to the spike) (Figure 4). In Florida, the plant typically has 4-6 spikes with one or two spikes attached below the terminal cluster. The spike resembles a goosefoot, hence the name.

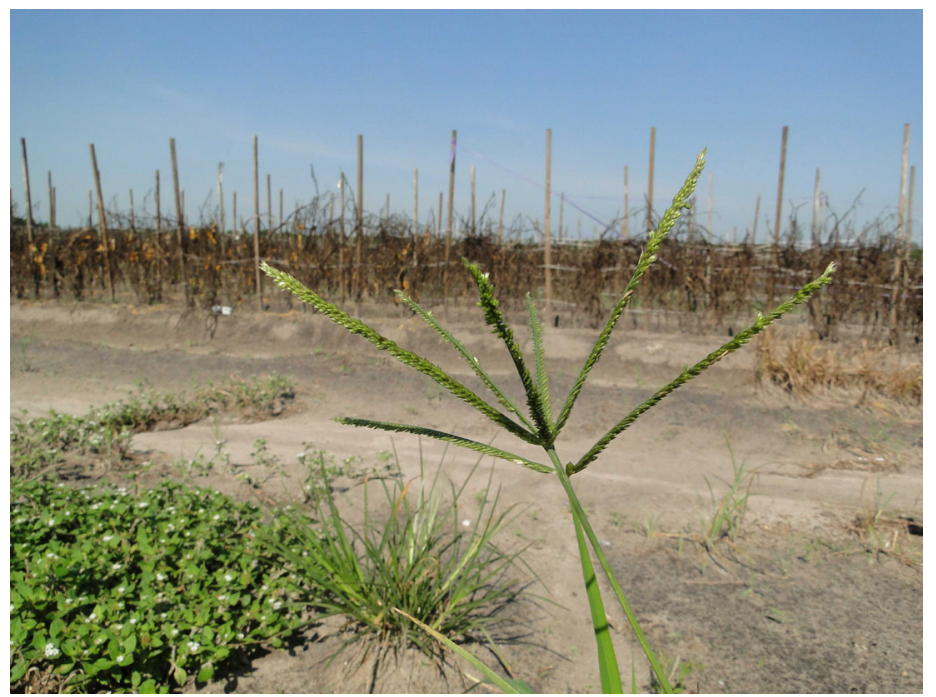

Figure 4. Seed head

Credits: Nathan S. Boyd, UF/IFAS

\section{Fruit and Seeds}

The fruit are tiny, reddish brown, one-seeded, and enclosed in a thin covering. Seed production reports vary significantly with some authors reporting 140,000 seeds per plant (Chin 1979).

\section{Similar Species}

E. indica is closely related to Eleusine coracana (African finger millet) and superficially resembles one of the crabgrasses (Digitaria spp.) because of the finger-like spikes of its inflorescence and its growth habit, but it is actually quite different. The foliage of goosegrass is shiny, as compared to the dull-colored foliage of crabgrass. The finger-like spikes of crabgrass are narrower than those of goosegrass, are usually green or reddish green, and less shiny. Spikelets of goosegrass have 3-7 lemmas (lower bracts enclosing the florets) whereas crabgrass has a single pair. Most species of crabgrass root along the nodes of growing stems, while goosegrass does not root at the nodes. 


\section{Plant Biology}

Goosegrass is a common annual turf and horticultural weed found throughout Florida. It grows well in compact, wet soil and competes successfully with warm-season and cool-season turf grasses especially with thin, open disturbed turf. It is considered an aggressively intrusive weed due to its vigorous growth and abundant seed production (Holm et al. 1979). Seeds germinate at or near the surface of moist soils with temperatures above $65^{\circ} \mathrm{F}$ (Chauhan and Johnson 2008) and are not affected by a pH range from 5-10. Seed germination completely ceases if seeds are buried deeper than 3 inches $(7.6 \mathrm{~cm}$ ) (Chauhan and Johnson 2008; Odero et al. 2015). Persistence is due to abundant seed production and tolerance to close mowing. Goosegrass can grow up to 3 feet tall (1 m) (Uva et al. 1997) and spreads by reseeding itself.

\section{Management}

\section{Physical and Cultural Control}

Physically removing goosegrass by hand early after emergence is the best approach to control in container production. If weeds are left to grow, removal is difficult, and the roots of the weed can remove large volumes of potting soil from the containers. If plants are found growing near pots on the ground, removal should be made before seed production occurs. Always check liners for the presence of weeds before potting up to larger sizes. Plants that are allowed to set seeds will further exacerbate the problem because the seeds will germinate on potting media surfaces.

In field production, plants can be disked or tilled in drive rows. Mowing will not eradicate plants due to their prostrate growth habit.

\section{Chemical Control}

There are a variety of pre and postemergence herbicides with activity on goosegrass (Tables 1 and 2).

\section{PREEMERGENCE}

Many of the preemergence herbicides commonly used in and around ornamentals provide effective control of goosegrass. Group 3 herbicides (dithiopyr, oryzalin, pendimethalin, prodiamine, etc.) can be applied to many different ornamentals in nurseries and landscapes and typically provide excellent goosegrass control if used according to label instructions. These products are often applied alone or are combined with another herbicide to broaden the spectrum of weed control. Other effective active ingredients include dimethenamid-p and indaziflam. A full list of preemergence herbicides including trade names, active ingredients, use sites, and efficacy rankings are listed in Table 1.

\section{POSTEMERGENCE}

Goosegrass can be controlled by a variety of postemergence herbicides, but the best choice will depend upon the ornamental species, the site in which the application will be made, and the use pattern needed. For example, several graminicides are available, including clethodim (Envoy ${ }^{\circledR}$ Plus), fenoxaprop-p-ethyl (Acclaim ${ }^{\circledR}$ Extra), fluazifop-pbutyl (Fusilade ${ }^{\circledR}$ II), and sethodydim (Segment $\left.{ }^{\circledR}\right)$. These herbicides can be applied over-the-top of many different ornamental plants but will only control grassy weeds (not broadleaf weeds or sedges). The use of crop oil concentrates or surfactants is typically recommended when applying graminicides in order to increase weed control; however, these products may also increase the chance of crop phytotoxicity with some ornamental species. Closely read label instructions for each individual herbicide in order to achieve the best control possible while minimizing the chance of crop damage. When goosegrass is still small, contact action herbicides such as diquat (Reward) or pelargonic acid (Scythe) may be used, but only as a directed application. Larger goosegrass may be controlled by glufosinate (Finale) or glyphosate (RoundUp, etc.).

Various populations of goosegrass around the world have become resistant to the postemergent herbicides glyphosate, glufosinate, paraquat, sethoxydim (and other Group 1 or ACCase inhibitors), and imazapyr (Heap 2016). A Florida population of paraquat-resistant goosegrass was found in the Manatee County area (Buker et al. 2002). It is important to rotate through different herbicide modes of action from season to season or year to year in order to avoid the development of herbicide resistant weed populations. A partial list of postemergence herbicides labeled for use in and around ornamentals that provide control of goosegrass is given in Table 2. Efficacy of postemergence herbicides is strongly influenced by weed size, growth stage, and environmental factors. Read and follow all herbicide label guidelines in order to achieve the best results.

\section{References}

Buker, R. S. III, S. T. Steed, and W. M. Stall. 2002. "Confirmation and Control of a Paraquat-Tolerant Goosegrass (Eleusine indica) Biotype." Weed Technology: 16(2): 309-313. 
Chauhan, B. S., and D. E. Johnson. 2008. "Germination Ecology of Goosegrass (Eleusine indica): An Important Grass Weed of Rainfed Rice." Weed Science 56:699-706.

Chin, H.F. 1979. "Weed Seed-A Potential Source of Danger." Pg.115-119 in L. T. Kwee, ed Proceedings of the Plant Protection Seminar. Kuala Lumpur, Malaysia, Malaysian Plant Protection Society.

Heap, I. The International Survey of Herbicide Resistant Weeds. Online. Internet. Wednesday, August 10, 2016. http://www.weedscience.org/default.aspx

Holm, L., J. V. Pancho, J. P. Herberger, and D. L. Plucknett. 1979. A Geographical Atlas of World Weeds. John Wiley and Sons.

Mallory-Smith, Carol A., and E. James Retzinger Jr. 2003. "Revised Classification of Herbicides by Site of Action for Weed Resistance Management Strategies 1." Weed Technology 17(3): 605-619.

Odero, D. C., R. Rice, and L. Baucum. 2015. Biology and Control of Goosegrass in Sugarcane. SS-AGR-367. Gainesville: University of Florida Institute of Food and Agricultural Sciences. http://edis.ifas.ufl.edu/sc096

Uva, R. H., J. C. Neil, and J. M. DiTomaso. 1997. Weeds of the Northeast. Ithaca: Cornell University Press. 


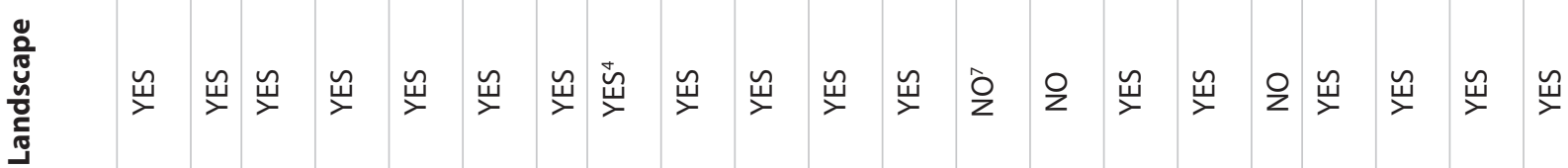

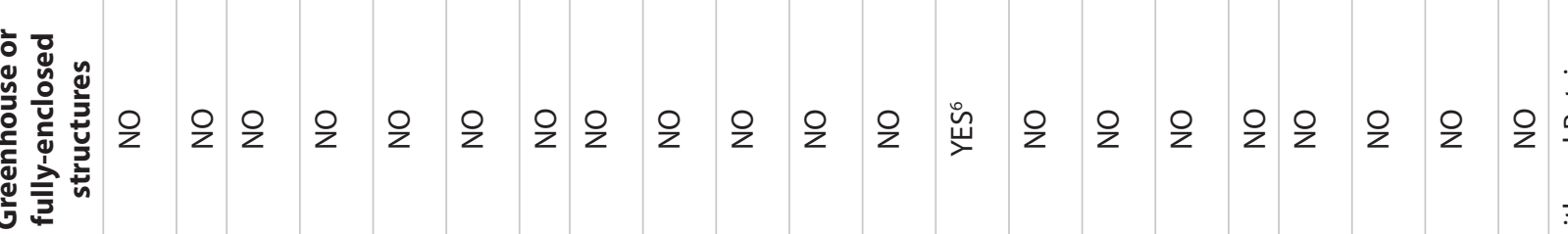

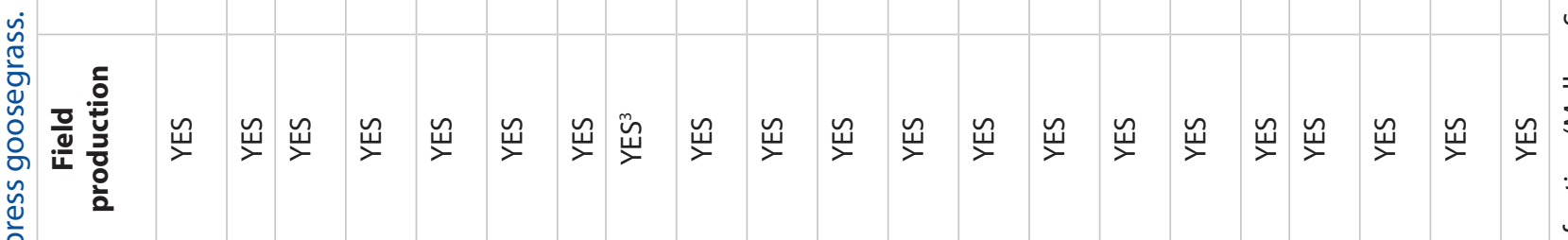

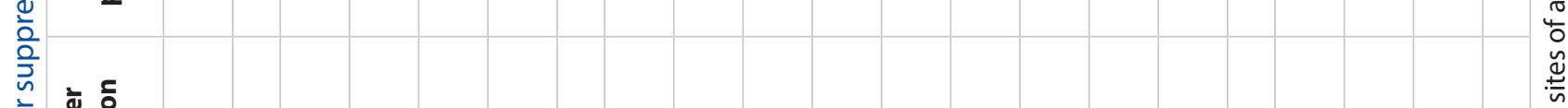

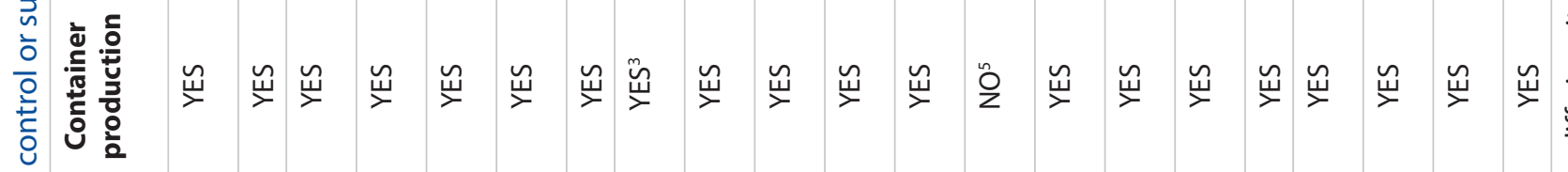

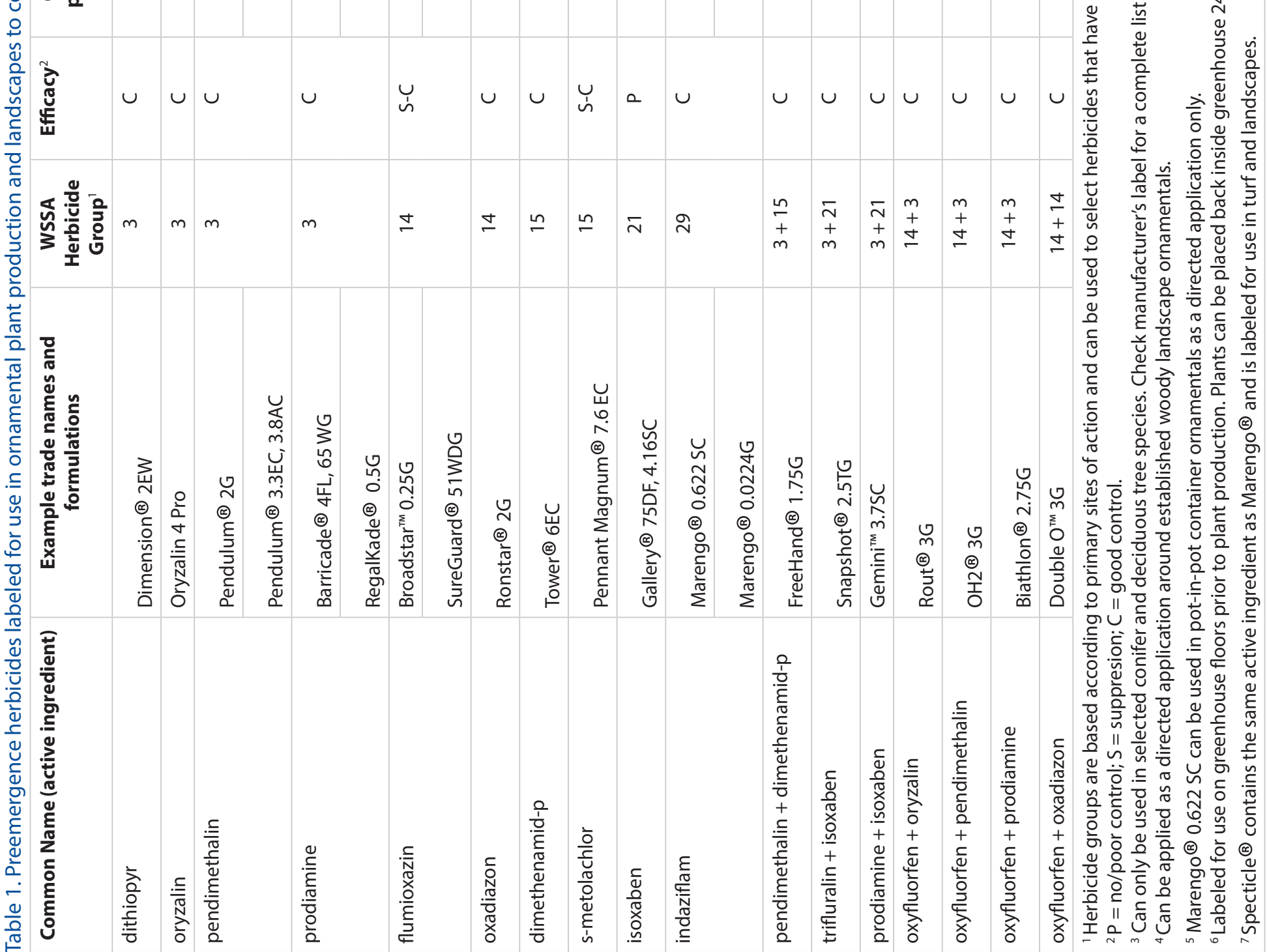




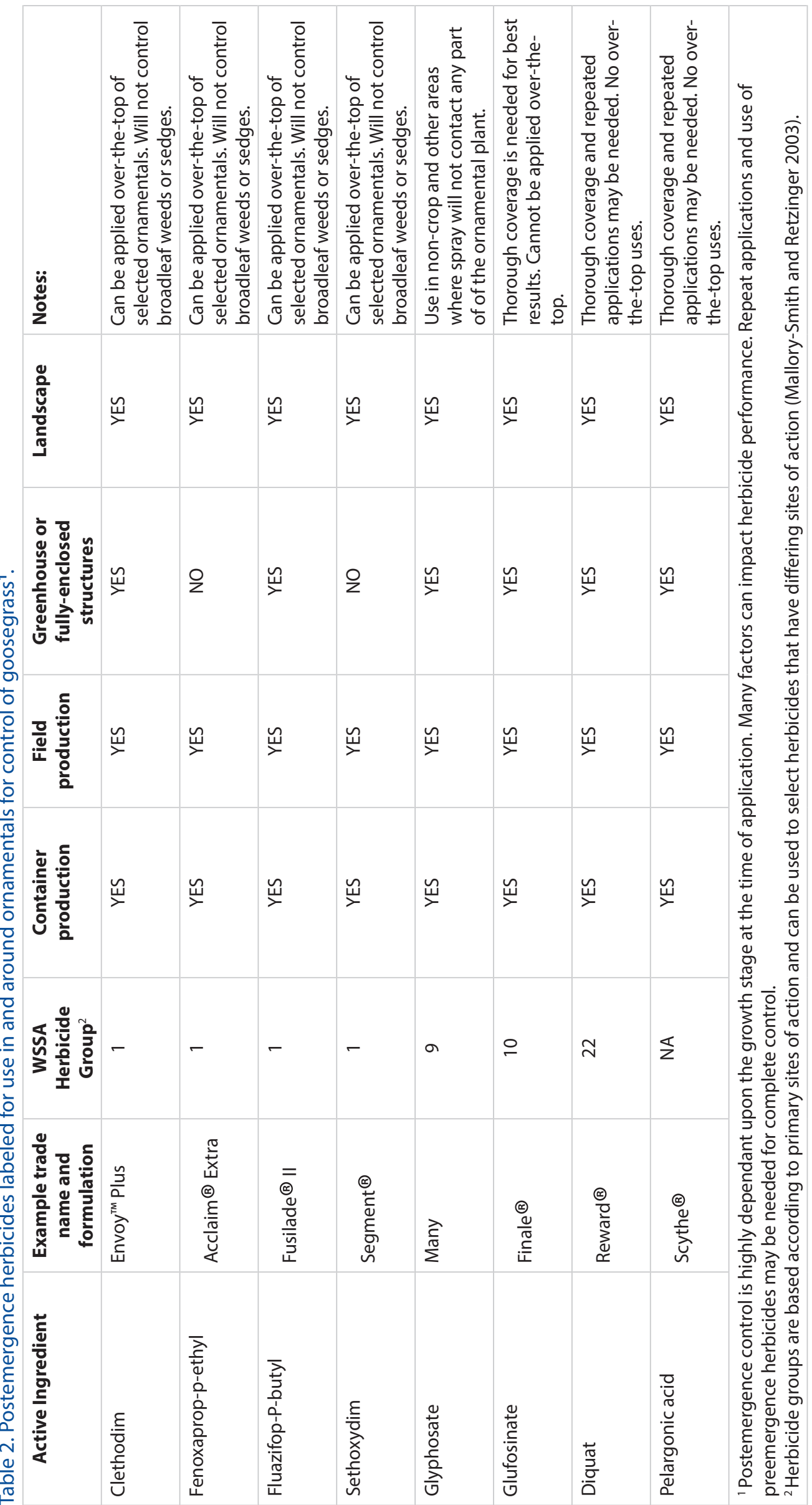

